\title{
Genetic similarity as a measure for connectivity between fragmented populations of the moor frog (Rana arvalis)
}

\author{
C. C. VOS* ${ }^{*}$, A. G. ANTONISSE-DE JONG \\ \& M. J. M. SMULDERS: \\ $\dagger$ Alterra, PO Box 47, NL-6700 AA Wageningen, The Netherlands, $\ddagger$ Plant Research International, PO Box 16, \\ NL-6700 AA Wageningen, The Netherlands and §Centre for Biometry Wageningen, PO Box 16, \\ NL 6700 AA Wageningen, The Netherlands
}

\begin{abstract}
Genetic differentiation among populations of the moor frog (Rana arvalis) was tested on a spatial scale where some dispersal between populations is expected to occur, in a landscape in The Netherlands that has become fragmented fairly recently, in the 1930s. Five microsatellite loci were used, with $2-8$ alleles per locus. $F_{\text {IS }}$ was 0.049 across loci, and most populations were in HW equilibrium. The degree of population subdivision was low $\left(F_{\mathrm{ST}}=0.052\right)$. A significant positive correlation between genetic distance and geographical distance was found, indicating a limitation in dispersal among populations due to distance. To test the impact of the landscape mosaic on the connectivity between patches, distance measures were corrected for relative amounts of habitat types with known positive or negative influence on moor frog dispersal. Notably, the resistance variable for the fraction of negative linear elements (roads and railways) gave a higher explanatory value than geographical distance itself. Therefore, it is particularly the number of barriers (roads and railways) between populations that emerges as a factor that reduces exchange between populations. It is concluded that genetic techniques show promise in determining the influence of landscape connectivity on animal dispersal.
\end{abstract}

Keywords: dispersal, gene flow, landscape resistance, microsatellite marker, metapopulation, Rana arvalis.

\section{Introduction}

Fragmentation is the result of the destruction of habitat suitable for a species, resulting in small fragments, or patches, that are separated by unsuitable habitat or other barriers (Hanski \& Gilpin, 1991; Opdam et al., 1993; Hanski \& Simberloff, 1997). Many species have a naturally disjunct distribution pattern, associated with the heterogeneity of the landscape. For instance, the moor frog (Rana arvalis) requires both terrestrial and aquatic habitats during its life cycle, and so migrations between spatially separated habitats occur naturally in its life history. However, if habitat fragmentation is the result of man-made changes in land use, we want to know to what extent species are coping with this fragmentation of their habitat. An important prerequisite for regional survival is that connectivity within the habitat network (or metapopulation, Levins, 1970) is sufficient to enable individuals to disperse between

*Correspondence. E-mail: c.c.vos@alterra.wag-ur.nl patches (Opdam, 1990; Wiens, 1997). For grounddwelling species with low dispersal capacity, such as frogs, connectivity depends on the distance between suitable habitat patches and on the relative resistance of the landscape mosaic between patches (Forman \& Godron, 1986; Wiens, 1997; Bennett, 1999). Hartung (1991) demonstrated that the movement patterns of moor frogs are influenced by the landscape mosaic: moor frogs prefer ditches and hedgerows and avoid dry and open areas. A negative effect of road density on the distribution pattern of the moor frog was demonstrated in an earlier study (Vos \& Chardon, 1998).

Although quantifying dispersal distances has a high research priority, progress is slow, as these studies tend to be very time-consuming and there are many methodological problems. In particular, long-distance dispersal, which might be an important factor determining recolonization success, is difficult to measure directly (Crochet, 1996; see Turchin, 1998; for a review on dispersal study methods). 
The demographic processes that define metapopulation dynamics influence the genetic structure of populations (McCauley, 1991). An effect of limited dispersal in fragmented landscapes is the reduction of gene flow between populations. In small and isolated populations, genetic drift may increase differentiation between populations. Several studies have demonstrated a correlation between genetic dissimilarity and geographical distance of populations (see Avise, 1994 for examples of different taxa; Crochet, 1996 for a review on birds). These studies were generally conducted over large geographical ranges, comparing populations that have been separated for a long time. If genetic differentiation can be demonstrated on a microscale, and if it can be correlated with the connectivity of the landscape, it may be an effective instrument to quantify dispersal.

In this study, we tested whether genetic differentiation among populations of the moor frog can be found on a spatial scale where some dispersal between populations is expected to occur, and in a landscape that has become fragmented fairly recently (in the 1930s). In addition, we tested whether genetic differentiation is related to the geographical distance between populations. Five microsatellite loci were employed as genetic markers to reveal differences between populations on a small spatial and temporal scale (Scribner et al., 1994; Waser \& Strobeck, 1998). The markers were generated using microsatellitecontaining sequences from other Rana species present in the EMBL database, whose flanking sequences were conserved across related species (Smulders et al., 1997, 2000) and could be used in Rana arvalis. To analyse the impact of the landscape mosaic on the connectivity between patches, we developed distance measures that incorporated the relative resistance of habitat types and linear elements.

\section{Materials and methods}

\section{Study area}

The study was carried out in the eastern part of an area where in 1993 an inventory was made of the moor frog in all potential reproduction sites in the southwest of the province of Drenthe, The Netherlands (Fig. 1; Vos \& Chardon, 1998). The moor frog is found in moist, nutrient-poor habitats, often on peat or sandy soils with impermeable layers or high groundwater tables (Podloucky, 1987; Hartung, 1991). The aquatic part of the moor frog habitat consists of moorland ponds and swamps. The terrestrial habitat consists mainly of moorlands dominated by Molinia caerulea and Erica tetralix, but also includes hedgerows and mixed woods with a well- developed herb layer. The suitable habitat patches in the study area are remnants of a (semi) natural ecosystem that totally covered the study area until the beginning of the twentieth century (Historische Atlas Drenthe, 1989). In the 1930s large parts of Drenthe were rapidly brought into cultivation and the moorland became fragmented. The present fragmentation of moorland has therefore existed for approximately 60 years. As moor frogs become adult in their third (calendar) year (Hartung, 1991), this implies that approximately 30 generations have developed since the fragmentation of the area. Estimations of the annual adult mortality are between $40 \%$ (Loman, 1987) and $60 \%$ (Ryser, 1988), which means that overlapping generations do occur, reducing the effective number of generations.

\section{Geographical distance and landscape resistance}

The spatial configuration of the moor frog habitat, the habitat types in the landscape matrix between suitable habitat patches, and linear elements such as roads, railways and ditches were recorded from a topographical map 1:25000 using a Geographic Information System (Fig. 1). Distances between all moorland ponds were calculated from pond border to border. To correct for the relative resistance of the landscape mosaic, area and length were calculated of habitat types and linear landscape elements in a $200-\mathrm{m}$ wide strip between ponds (Table 1a). Habitat types that are avoided by moor frogs, such as dry and open areas (Hartung, 1991), or that form relative barriers, such as roads and railways, were considered negative landscape elements that increase the resistance of the landscape. Two road types were present in the study area: paved roads smaller than $4 \mathrm{~m}$ and paved roads of 4-7 m width. To aggregate effects of these road types, road lengths were weighted based on the mean traffic volume per road type (Provincie Drenthe, 1994; see also Vos \& Chardon, 1998). Habitat types that are preferred by moor frogs (Hartung, 1991) or that resemble moor frog habitat were regarded as positive landscape elements that reduce resistance (Forman, 1995). In Table 1a the mean, maximum and minimum values of these landscape elements are listed. Three resistance variables were calculated to correct for the relative amounts of these positive and negative elements (Table $1 b$ ). In $D^{*} R_{L}$ the distance $D$ is corrected with $R_{L}$, the fraction of negative linear elements: roads and railways. In $D^{*} R_{A}$ the distance is corrected with $\mathrm{R}_{\mathrm{A}}$, the fraction of negative areas: agricultural land and built-up area. In $\mathrm{D}^{*} \mathrm{C}_{\mathrm{L}}$ the distance is corrected with $C_{L}$, the fraction of positive linear elements: hedgerows and ditches. 


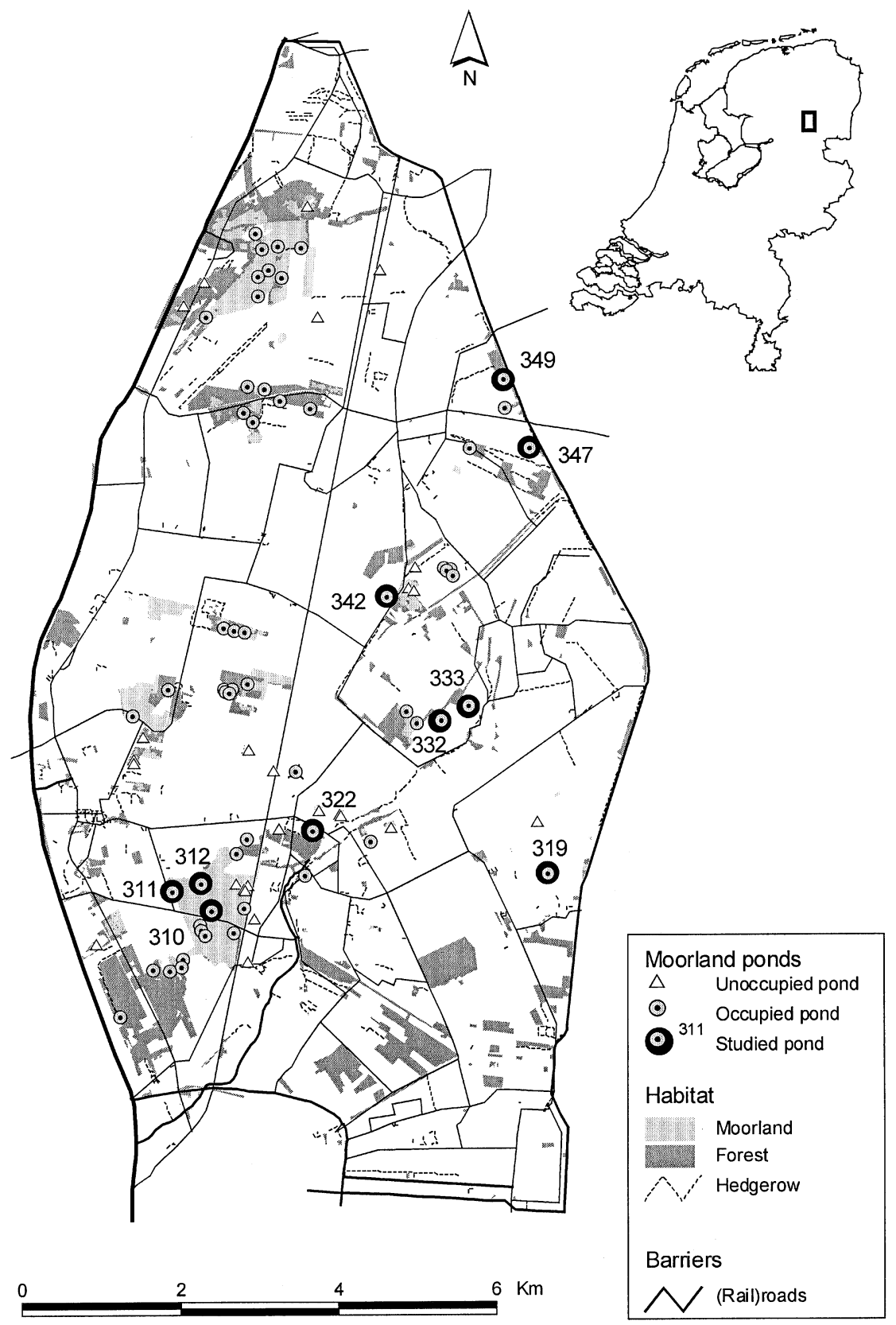

Fig. 1 The study area in south-west Drenthe. Ditches are not indicated.

\section{Sampling}

Ten populations were sampled in the study area in 1995 (Fig. 1). Three samples were taken in ponds in the same moorland at short distances from each other (ponds 310 , 311 and 312, Fig. 1). The distances between the three sites varied from 0.28 to $0.51 \mathrm{~km}$ and the landscape between the three breeding sites consisted of continuous moorland, which is suitable terrestrial habitat for the moor frog. Seven populations were sampled from moorland ponds at distances ranging from 0.5 to $8 \mathrm{~km}$ from the main moorland. These ponds were separated by agricultural landscape (Fig. 1). To get an impression of the overall genetic diversity, one population (Beuven) was sampled at $20 \mathrm{~km}$ distance from the study area and a second population (Heerenven) at approximately $150 \mathrm{~km}$ distance. An indication for the population size was derived from the number of egg clumps, based on estimates from 1993 (Vos \& Chardon, 1998; Table 2). Since females lay a single egg clump, the number of egg clumps is an estimate for the reproductive population size (Griffiths \& Raper, 1994). For the two reference populations, the number of egg clumps in 1995 was taken as an estimate for population size. We sampled 
Table 1a Habitat types and linear landscape elements that were measured in a strip of $200 \mathrm{~m}$ width between moorland ponds. Mean values, standard deviation, maximum and minimum values are given

\begin{tabular}{lcrc}
\hline Habitat types and linear landscape elements & Mean \pm standard deviation & Maximum & Minimum \\
\hline D, Distance between ponds (km) & $3.72 \pm 2.03$ & 7.64 & 0.28 \\
SA, Strip Area (D*200) (ha) & $75.29 \pm 40.62$ & 153.71 & 6.8 \\
NL, Negative Linear elements: roads (weighted for & $1.70 \pm 1.19$ & 4.37 & 0 \\
car density) and railways & $63.60 \pm 37.78$ & 142.41 & 0 \\
NA, Negative Area: agricultural fields, built-up areas (ha) & $11.54 \pm 6.62$ & 28.37 & 0.54 \\
PL, Positive Linear elements: hedgerows, ditches (km) & & & \\
\hline
\end{tabular}

Table 1b The calculation of the resistance variables: $D^{*} R_{L}, D * R_{A}$ and $\mathrm{D}^{*} \mathrm{C}_{\mathrm{L}}$

\begin{tabular}{|c|c|}
\hline Resistance variable & Calculation of resistance variable \\
\hline $\begin{array}{l}D * R_{L} \text { Distance weighted } \\
\text { for the fraction of } \\
\text { negative linear elements }\end{array}$ & $\begin{array}{l}\mathrm{R}_{\mathrm{L}}=(\mathrm{NL}+\mathrm{D}) / \mathrm{D} \text { being the length of negative } \\
\text { linear elements relative to the distance between } \\
\text { two ponds. } \mathrm{R}_{\mathrm{L}} \text { is a figure between } 1 \text { and infinity, } \\
\text { without dimension. It increases with NL. }\end{array}$ \\
\hline $\begin{array}{l}\mathrm{D} * \mathrm{R}_{\mathrm{A}} \text { Distance weighted } \\
\text { for the fraction of } \\
\text { negative area }\end{array}$ & $\begin{array}{l}\mathrm{R}_{\mathrm{A}}=(\mathrm{NA}+\mathrm{SA}) / \mathrm{SA} \text { being the negative area } \\
\text { relative to the total area in a strip of } 200 \mathrm{~m} \text { wide } \\
\text { between two ponds. } \mathrm{R}_{\mathrm{A}} \text { is a figure between } 1 \text { and } \\
\text { infinity, without dimension. It increases with } \\
\text { NA. }\end{array}$ \\
\hline $\begin{array}{l}D * C_{L} \text { Distance weighted } \\
\text { for the fraction of } \\
\text { positive linear elements }\end{array}$ & $\begin{array}{l}C_{L}=D /(P L+D) \text { being the length of positive } \\
\text { linear elements relative to the distance between } \\
\text { two ponds. } C_{L} \text { is a figure between } 1 \text { and } 0, \\
\text { without dimension. It decreases asymptotically } \\
\text { to } 0 \text { with increasing PL. }\end{array}$ \\
\hline
\end{tabular}

Table 1c Correlations between genetic distance and geographical distance (D) and the distance variables weighted for relative resistance $\left(D^{*} R_{L}, D^{*} R_{A}\right.$, and $D^{*} C_{L}$ ) were tested with Mantel's randomization test

\begin{tabular}{lcc}
\hline Variable & Correlation & Significance \\
\hline $\mathrm{D}$ & 0.3136 & $P=0.042$ \\
$\mathrm{D}^{*} \mathrm{R}_{\mathrm{L}}$ & 0.3651 & $P=0.022$ \\
$\mathrm{D}^{*} \mathrm{R}_{\mathrm{A}}$ & 0.3285 & $P=0.039$ \\
$\mathrm{D}^{*} \mathrm{C}_{\mathrm{L}}$ & 0.3094 & $P=0.045$ \\
\hline
\end{tabular}

eggs, not tadpoles of mature frogs. In each population 20 egg clumps were sampled, taking several eggs from each clump. If less than 20 egg clumps were found, all available clumps were sampled. As moor frogs are explosive breeders with a very short breeding season, it is unlikely that males participate more than once in reproduction. Therefore, each clump was regarded as representing one reproducing couple. The eggs were raised in captivity and one egg of each clump was harvested in its tadpole stage. As old egg clumps cannot be distinguished with certainty from those of the common frog (Rana temporaria; Rahmel \& Eikhorst,
1988), species-specific teeth row numbers were checked at the tadpole stage. Due to small population size, mortality during raising and some tadpoles being identified as common frogs, the number of samples for most populations was under 20 (Table 2). Tadpoles were frozen in liquid nitrogen and stored at $-80^{\circ} \mathrm{C}$ until DNA extraction. DNA was extracted from nuclei as described by Bernatzky \& Tanksley (1986) as modified by Vosman et al. (1992).

\section{Microsatellite development}

The EMBL database was searched for Ranidae sequences using SRS (Sequence Retrieval System, version $3.1)$ in 1996. The sequences retrieved were subsequently screened for homology to an artificial sequence containing all mono-, di-, and trinucleotide motifs, plus two tetranucleotide repeats (ATCT and ATGT; Smulders et al., 1997) using FastA (Pearson \& Lipman, 1988). The first selection was for those sequences that had at least 12 mononucleotide repeat units, six repeat units for di and trinucleotide repeats, or four repeat units for the tetranucleotide repeats, allowing for one base pair mismatch internally. Some compound repeats were also 


\begin{tabular}{lcccc}
\hline Populations studied & $\begin{array}{c}\text { Moorland } \\
\text { pond }\end{array}$ & $\begin{array}{c}\text { Number of } \\
\text { sampled } \\
\text { individuals }\end{array}$ & $\begin{array}{c}\text { Number of } \\
\text { egg clumps }\end{array}$ & $\begin{array}{c}\text { Pond } \\
\text { area (ha) }\end{array}$ \\
\hline In study area & 310 & 19 & $100-250$ & 0.511 \\
& 311 & 6 & $5-15$ & 0.008 \\
& 312 & 17 & $50-100$ & 0.190 \\
& 319 & 17 & $100-250$ & 0.320 \\
& 322 & 16 & $100-250$ & 0.202 \\
Study area total & 332 & 18 & $100-250$ & 0.296 \\
Additional populations & 333 & 12 & $25-50$ & 0.121 \\
& 342 & 24 & $25-50$ & 0.643 \\
& 347 & 7 & $25-50$ & 0.181 \\
& 349 & 9 & $25-50$ & 0.329 \\
Overall total & Beuven & 20 & & \\
\hline
\end{tabular}

Table 2 Details of the sampled populations of Rana arvalis. The egg-clump classes are an indication for population size included. Primer pairs were designed flanking microsatellite loci using PRIMER (version 0.5, Whitehead Institute for Biomedical Research). A check whether the fragments amplified were alleles of the same microsatellite locus was done by purification of fragments from gel, reamplification, and direct sequencing using a Taq DyeDeoxy Terminator Cycle Sequencing kit on a ABI 370 sequencer.

\section{Amplification reactions and detection of microsatellite polymorphisms}

Each $25 \mu \mathrm{L}$ amplification reaction contained: $10 \mathrm{ng}$ genomic DNA, $0.32 \mu \mathrm{m}$ of each primer (Isogen, Maarssen, The Netherlands), $100 \mu \mathrm{M}$ deoxyribonucleotides, $50 \mathrm{~mm}$ $\mathrm{KCl}, 20 \mathrm{~mm}$ Tris- $\mathrm{HCl}$ (pH 8.4), $1.5 \mathrm{~mm} \mathrm{MgCl}_{2}, 0.05 \%$ $(\mathrm{v} / \mathrm{v})$ polyoxyethylene ether (W-1), and 0.5 U Taq DNA polymerase (Life Technologies). Amplifications were performed in microtitre plates using a Hybaid Omni Gene thermal cycler. Basically, the amplification conditions were: one cycle of $94^{\circ} \mathrm{C}$ for $3 \mathrm{~min} ; 30$ cycles of $55^{\circ} \mathrm{C}$ for $45 \mathrm{~s}, 72^{\circ} \mathrm{C}$ for $1 \min 45 \mathrm{~s}$, and $94^{\circ} \mathrm{C}$ for $45 \mathrm{~s}$. After the final cycle, one cycle of $55^{\circ} \mathrm{C}$ for $45 \mathrm{~s}$ and $72^{\circ} \mathrm{C}$ for $3 \mathrm{~min}$ was added (Bredemeijer et al., 1998). If necessary, the annealing temperature was lowered to $50^{\circ} \mathrm{C}$, and the number of cycles increased to 35 (details in Table 3).

Samples were prepared for PAGE electrophoresis by adding an equal volume of formamide, containing $10 \mathrm{~mm}$ $\mathrm{NaOH}$ and $0.05 \%$ bromophenol blue, to the reaction mixtures. After denaturation at $80^{\circ} \mathrm{C}$ for 5 min followed by quenching on ice, samples were analysed on vertical gels $(6 \%$ polyacrylamide, $8 \mathrm{M}$ urea, Tris-borate buffer) using a Model S2 sequencing gel electrophoresis apparatus (Life Technologies). The DNA bands were visualized by silver staining according to the Silver Sequence DNA sequencing system (Promega). The sizes of the PCR products were determined by comparison to an accompanying sequence reaction using pGEM-3Zf $(+)$ control DNA (Promega).

\section{Statistical analysis}

The frequencies of observed and expected heterozygotes, the mean number of alleles per locus and Wright's (1965) inbreeding coefficient $\left(F_{\text {IS }}\right)$ were calculated as measures for gene diversity within populations (Cockerham, 1973). Hardy-Weinberg equilibrium was tested using a Chi-squared test. The degree of differentiation between populations was estimated with Wright's $(1965)$ index of population subdivision $\left(F_{\mathrm{ST}}\right)$. Genetic divergence between populations was estimated by Nei's (1972) genetic distance. These analyses were carried out with POPGENE 1.31 (Yeh et al., 1999). Significance testing of $F_{\mathrm{ST}}$ values was done using permutations (ARLEQUIN 2.000, Schneider et al., 2000).

As a measure for the amount of gene flow between the studied populations, the correlation between genetic distance and various forms of geographical distance was tested with Mantel's randomization test (Mantel, 1967). A randomization test was used because the genetic distances are calculated pairwise and are thus not independent. The Mantel test for correlation is equivalent to a randomization test based on the $t$-statistic for testing whether the regression coefficient, of the regression of genetic distance on geographical distance, is 


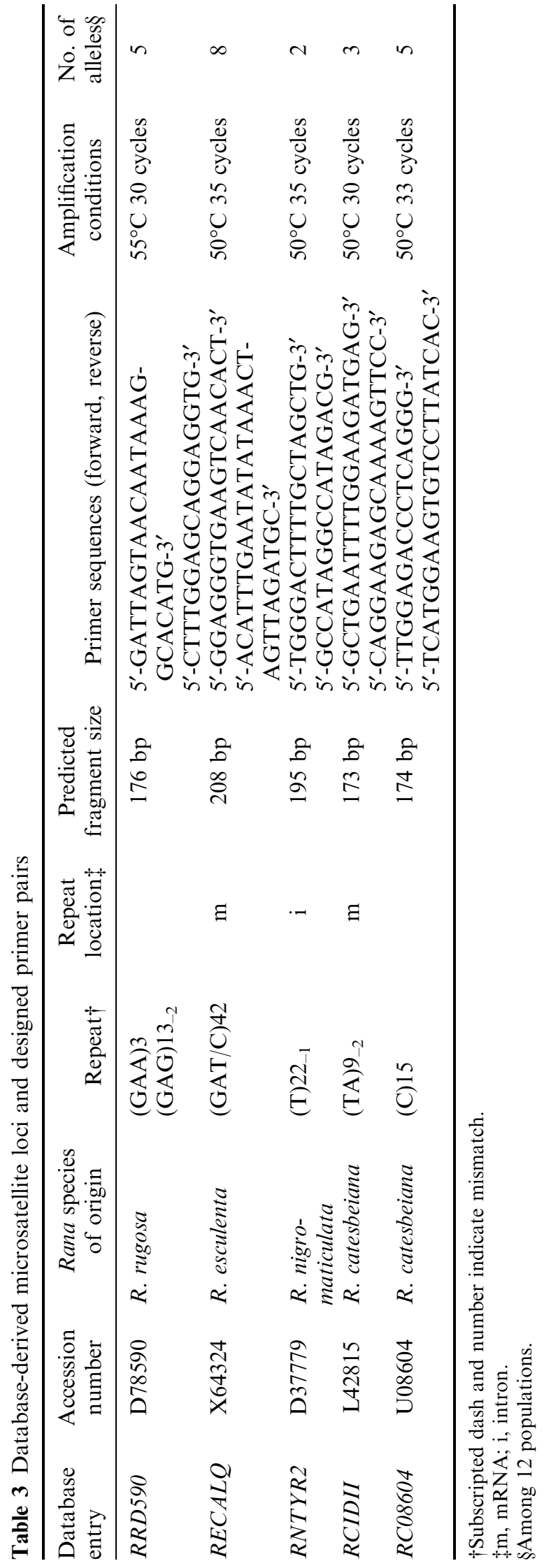

significantly different from zero (Manly, 1997). The multiple Mantel test was used to test whether genetic distance was related to both geographical distance as well as the distance variables weighted for relative resistance. The multiple Mantel test employs the randomization distribution of the $t$-statistics obtained by means of multiple regression, see Manly (1997). Each Mantel test uses 10000 randomizations to estimate the significance level.

\section{Results}

\section{Identification and characterization of microsatellites}

To generate STMS markers for use in the moor frog, microsatellite-containing sequences from Rana species were extracted from the EMBL and Genbank databases. In total, 167 sequences yielded 11 microsatellite sequences in nine accessions from species other than Rana arvalis. For these 11 microsatellites, primer pairs were designed and amplification was tested in a small number of moor frogs, and also in one common frog (Rana temporaria). After amplification, five loci (Table 3) were found to produce fragments that were polymorphic among the moor frogs. All microsatellite loci also amplified a product in the common frog.

Fragments produced by loci $R R D 590, R N T Y R 2$, and $R C 08604$ were purified from the gel, reamplified, and sequenced (not shown). When compared to the database sequence from the other Rana species, some point mutations were found throughout the fragment, but they were alleles of the respective loci, with different repeat lengths. The primers for $R C 08604$ amplified two sets of bands, four fragments between 174 and $180 \mathrm{bp}$, and five fragments between 311 and $320 \mathrm{bp}$. During the reamplification of the larger fragments, both a large and a small fragment were amplified. Upon sequencing, it became clear that one of the primer binding sites was present at the expected position (174 bp), but was apparently also present some $160 \mathrm{bp}$ downstream. Reanalysis of the original sequence from Rana catesbeiana, confirmed that a duplication of the primer binding site containing one bp mismatch was present at this downstream site. Polymorphisms among the fragments were present both upstream and downstream of the first primer binding site, hence the two groups of fragments did not reflect exactly the same variation, and we subsequently used the larger fragments (denoted as $R C 08604 d$ ) as representing the polymorphisms of this locus.

Using the five primer pairs, 183 frog samples from 12 populations were genotyped. The primer pairs amplified 2-8 alleles per locus (Table 3 ). The effective number of 
alleles ranged from 1.3 to 2.5. Linkage disequilibrium was not observed between any two loci in any of the populations (not shown). For RRD590, RECALQ, $R N T Y R 2$ and RCIDII no significant deviations from HW equilibrium were observed in nearly all populations $(P \geq 0.05)$. Locus $R C 08604 d$ was not in HW equilibrium in seven out of 12 populations $(P<0.05)$, and showed a shortage of some classes of heterozygotes. It is possible that this locus contained a null allele.

\section{Genetic differentiation between moor frog populations}

Population genetic parameters were estimated for the 10 populations in the study area, and for all populations (Table 4$)$. The observed heterozygosity $\left(H_{\mathrm{o}}\right)$ and the expected heterozygosity $\left(H_{\mathrm{e}}\right)$ for the five loci separately and for all loci together range from 0.2 to 0.6 , depending on the locus. Observed levels of heterozygosity were close to what was expected, except for locus $R C 08604 d$, which had a shortage of heterozygotes. $F_{\text {IS }}$ for all ponds $(0.052)$ and $F_{\text {IS }}$ for the 10 ponds within the study area (0.044) were low and not significantly different from zero $(P>0.05)$, giving no indication of loss of heterozygosity.

The degree of interpopulation genetic variation was limited, based on the $F$-statistic ( $F_{\mathrm{ST}}$ among all populations was 0.065 , Table 4). The subdivision between the populations within the study area was $F_{\mathrm{ST}}=0.052$, which gives an estimate of 4.6 dispersers between populations per generation (Table 4 ). $F_{\mathrm{ST}}$ among the 10 populations was not significant $(P>0.05)$. For the separate loci, only the $F_{\mathrm{ST}}$ value of locus $R C 08604$ was significant $(P=0.033)$. It is possible that this locus has a null allele, which could inflate the $F_{\mathrm{ST}}$ value. However,
Fig. 2 Relative contribution of $D^{*} R_{L}$ (distance corrected for the fraction of negative linear elements) to the between-ponds connectivity, shown for three ponds: 310,319 and 322 . The line length represents the decrease in connectivity due to landscape resistance. The positions of the ponds (black dots with numbers) are plotted according to their geographical configuration (Fig. 1). The grey dots are a representation of the impact of landscape resistance on this configuration expressed as a virtual distance.

we do not expect a systematic effect of a null allele on the matrix of genetic distances between pairs of populations as used in the following section.

\section{Genetic distance and connectivity}

The impact of the landscape mosaic on the connectivity between ponds was expressed in three resistance variables: distance corrected for the fraction of negative linear elements $\left(D^{*} R_{L}\right)$, the fraction of negative area $\left(D^{*} R_{A}\right)$ and the fraction of positive linear elements $\left(D^{*} C_{L}\right)$. A comparison of the geographical distances between ponds with and without correction for relative amount of negative linear elements $\left(D^{*} R_{L}\right)$ is shown in Fig. 2. In cases where no barriers between ponds are present, the distance remains the same (e.g. from pond 310-312). In contrast, when many barriers are present, the weighted distance can be more than doubled compared to the geographical distance (e.g. between ponds 322 and 342).

Significance levels of the Mantel test between genetic distance and various versions of geographical distance, for all pairs of populations, are given in Table 1c. Genetic distance was positively related with geographical

Table 4 Population genetic parameters for Rana arvalis, estimated using the five microsatellite loci

\begin{tabular}{|c|c|c|c|c|c|c|c|}
\hline \multirow[b]{2}{*}{ Locus } & \multirow{2}{*}{$\begin{array}{l}\text { Sample } \\
\text { size }\end{array}$} & \multicolumn{2}{|c|}{ Heterozygosity } & \multicolumn{3}{|c|}{$F$-statistics } & \multirow[b]{2}{*}{$\mathrm{Nm}$} \\
\hline & & $H_{\mathrm{o}}$ & $H_{\mathrm{e}}$ & $F_{\text {IS }}$ & $F_{\text {IT }}$ & $F_{\mathrm{ST}}$ & \\
\hline \multicolumn{8}{|c|}{ The 10 populations in the study area } \\
\hline$R R D 590$ & 274 & 0.256 & 0.231 & -0.139 & -0.107 & 0.026 & 9.5 \\
\hline$R E C A L Q$ & 272 & 0.213 & 0.205 & -0.083 & -0.051 & 0.030 & 8.2 \\
\hline$R N T Y R 2$ & 260 & 0.339 & 0.356 & 0.005 & 0.035 & 0.030 & 8.0 \\
\hline$R C I D I I$ & 278 & 0.532 & 0.600 & 0.079 & 0.143 & 0.069 & 3.4 \\
\hline RC08604d & 262 & 0.366 & 0.497 & 0.171 & 0.226 & 0.067 & 3.5 \\
\hline Mean & 269 & 0.341 & 0.378 & 0.044 & 0.093 & 0.052 & 4.6 \\
\hline SD & & 0.123 & 0.170 & & & & \\
\hline \multicolumn{8}{|c|}{ All 12 populations } \\
\hline Mean & 341 & 0.337 & 0.384 & 0.052 & 0.114 & 0.065 & 3.6 \\
\hline SD & & 0.106 & 0.159 & & & & \\
\hline
\end{tabular}

$N m$, gene flow estimated from $F_{\mathrm{ST}}: N m=0.25\left(1-F_{\mathrm{ST}}\right) / F_{\mathrm{ST}}$. 

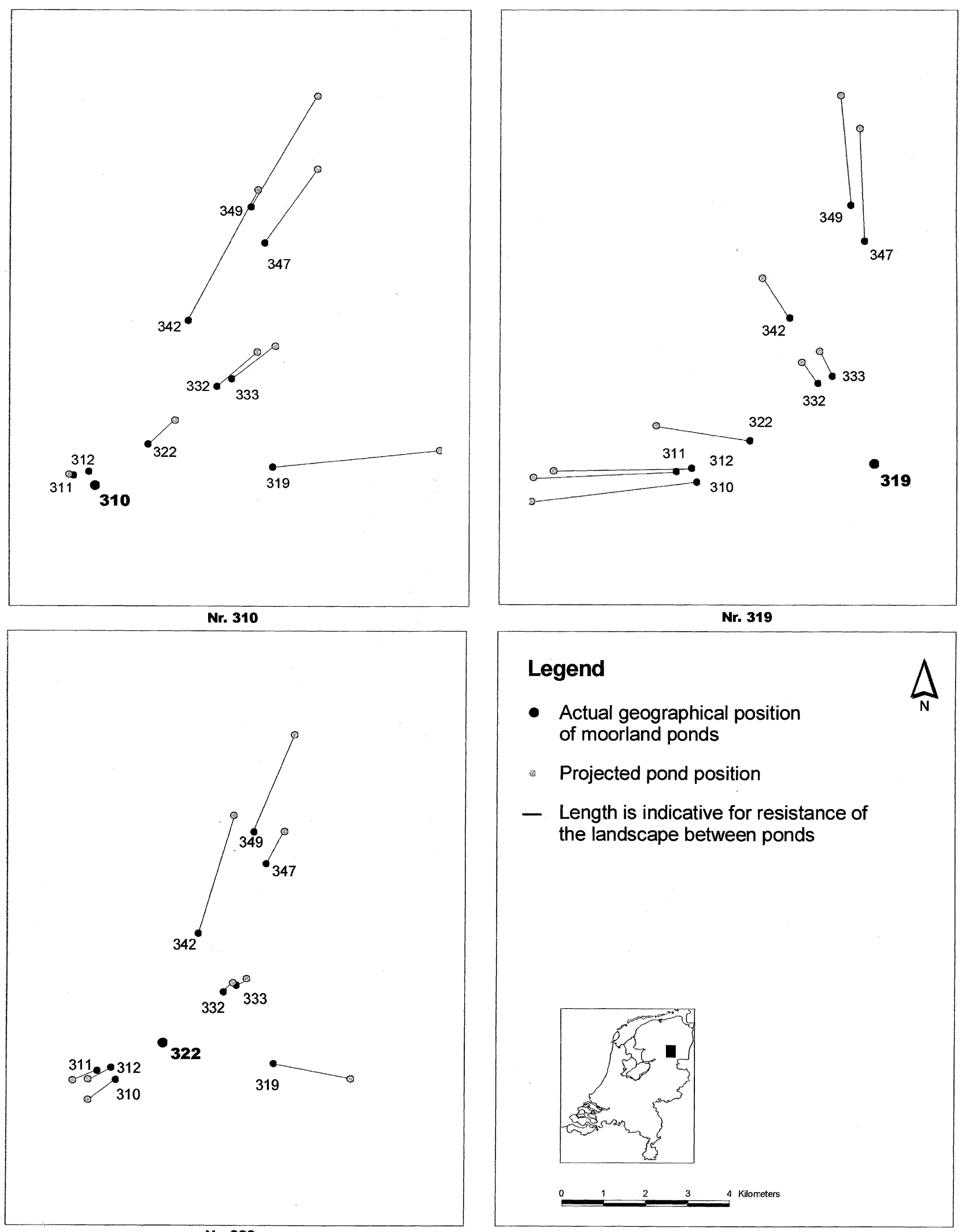

(c) The Genetics Society of Great Britain, Heredity, 86, 598-608. 
distance $(P=0.042)$ and also with the resistance variables $\mathrm{D}^{*} \mathrm{R}_{\mathrm{L}}(P=0.022), \mathrm{D}^{*} \mathrm{R}_{\mathrm{A}}(P=0.039)$ and $\mathrm{D}^{*} \mathrm{C}_{\mathrm{L}}$ $(P=0.045)$. The relationship with $\mathrm{D}^{*} \mathrm{R}_{\mathrm{L}}$, the distance weighted for the fraction of negative linear elements, was strongest. In a model with geographical distance and $\mathrm{D}^{*} \mathrm{R}_{\mathrm{L}}$, in a multiple Mantel test, $\mathrm{D}^{*} \mathrm{R}_{\mathrm{L}}$ was still significant $(P=0.049)$. Conversely, when geographical distance was added to a model with $\mathrm{D} * \mathrm{R}_{\mathrm{L}}$, geographical distance did not have a significant effect on genetic distance $(P>0.13)$. Therefore a model with the resistance variable $D^{*} R_{L}$ is sufficient.

\section{Discussion}

The genetic differentiation of moor frog populations in the study area was small. However, the correlation between genetic distance and geographical distance measures was significant. These results show that the dispersal rate between populations decreased with distance, and that this can be measured over small distances (maximum $7.6 \mathrm{~km}$ ) in a recently fragmented landscape. The variable that incorporated the fraction of barriers (roads and railways) gave a higher explanatory value than geographical distance. This indicates that particularly the number of barriers reduced the exchange between populations.

The genetic variation between populations in our study area was low $\left(F_{\mathrm{ST}}=0.052\right.$ and not significantly different from zero). Hitchings \& Beebee (1997) found $F_{\mathrm{ST}}=0.388$ among urban populations of $R$. temporaria that were $0.8-4.4 \mathrm{~km}$ apart, using isozymes. $F_{\mathrm{ST}}$ among rural populations up to $93 \mathrm{~km}$ apart was much lower (0.145), suggesting that agricultural land was considerably less of a barrier than the urban landscape. However, direct comparison of $F$-statistics derived from allozymes (Rafínski \& Babik, 2000) and microsatellites is difficult, as the latter tend to give larger genetic distances and lower levels of inbreeding (in the toad Bufo bufo, Scribner et al., 1994).

\section{Distance, landscape resistance and dispersal}

Three measures describing landscape features that might contribute to landscape resistance (Table 1b) were analysed separately. One could argue that a combined resistance measure would be more appropriate. However the relative weight of positive and negative effects in a combined measure would be arbitrary. By keeping them separate it was possible to gain insight into which habitat type or linear landscape elements most strongly determine landscape resistance. Distance corrected for the number of barriers (roads and railways) gave a stronger relation with genetic distance than geographical distance. In an earlier study in the same area, a negative effect of road density was demonstrated on the distribution pattern of the moor frog (Vos \& Chardon, 1998). The probability that a pond was occupied by the moor frog lowered with increasing road density in a radius of $750 \mathrm{~m}$. The mortality risk of amphibians crossing roads is well known (Van Gelder, 1973; Berthoud \& Müller, 1983; Heine, 1987; Hels, 1999). Hitchings \& Beebee (1997) also found a stronger correlation between genetic distance and geographical distance weighted for relative resistance, in their case a correction for the amount of post-1932 urban development. These results indicate that for amphibians the relative resistance of the landscape is an important component when estimating dispersal between populations.

The moor frog habitat of our study area has become fragmented fairly recently, through wide-scale cultivation in the 1930s. The maximum number of generations since the fragmentation of the habitat is 30 , but the effective number is less considering the occurrence of overlapping generations. The present genetic structure may to some extent still reflect the former situation. Therefore the estimate of the number of migrants per generation based on our $F_{\mathrm{ST}}$ values $(\mathrm{Nm}=4.6)$ may be an overestimation for the present landscape. No clear relationship between estimated population sizes (derived from egg clump counts) and the number of alleles or loss of heterozygosity was found. In amphibians, population size can fluctuate considerably between years and turnover of populations is frequent (Pechmann \& Scott, 1991). Therefore, a proper interpretation of the present genetic structure in terms of population size and age would require information about the presence and size of populations in time.

One approach to get a better insight into what extent genetic differentiation is related to reduced dispersal, is to compare genetic structure in landscapes with different degrees of habitat fragmentation. To test this method a study is currently being carried out in a landscape with less suitable habitat and higher traffic intensity of the road network.

\section{Acknowledgements}

Bioinformatic facilities of the CMBI Centre in Nijmegen, The Netherlands were used for database searches. Gerda Uenk, Gerda Sabatino and Paul Arens are thanked for their contribution to microsatellite development, Robbert Snep for the illustrations and Pim Arntzen and Ben Vosman for their comments on the manuscript.

\section{References}

AVISE, J. C. 1994. Molecular Markers, Natural History and Evolution. Chapman \& Hall, London. 
BENNETT, A. F. 1999. Linkages in the Landscape. The IUCN Forest Conservation Programme. IUCN Gland, Switzerland and Cambridge, UK.

BERNATZKY, R. AND TANKSLEY, S. D. 1986. Genetics of actin-related sequences in tomato. Theor. Appl. Genet., $\mathbf{7 2}$, 314-321.

BERTHOUD, G. AND MÜLLER, S. 1983. Installation de protection pour les batraciens; efficacité et effets secondaires. Rapport final, Département fédéral de l'Intérieur. Commission des recherches en matière de construction de routes, Lausanne.

BREDEMEIJER, G. M. M., ARENS, P., WOUTERS, D., VISSER, D. ET AL. 1998. The use of semi-automated fluorescent microsatellite analysis for tomato cultivar identification. Theor. Appl. Genet., 97, 584-590.

COCKerham, C. C. 1973. Analysis of gene frequencies. Genetics, 74, 679-700.

CRochet, P. A. 1996. Can measures of gene flow help to evaluate bird dispersal? Acta Oecologica, 17, 459-474.

FORMAN, R. T. T. 1995. Land Mosaics; the Ecology of Landscapes and Regions. Cambridge University Press, Cambridge.

FORMAN, R. T. T. AND GODRON, M. 1986. Landscape Ecology. Wiley, New York.

GRIFFITHS, R. A. AND RAPER, S. J. 1994. How many clumps are there in a mass of frog spawn? Br. Herpetol. Bull., 50, 14-17.

HANSKI, I. AND GILPIN, M. 1991. Metapopulation dynamics brief history and conceptual domain. Biol. J. Linn. Soc., 42, $3-16$.

HANSKI, I. AND SIMBERLOFF, D. 1997. The metapopulation approach, its history, conceptual domain, and application to conservation. In: Hanski, I. and Gilpin, M. (eds) Metapopulation Biology; Ecology, Genetics, and Evolution, pp. 5-26. Academic Press, San Diego.

HARTUNG, H. 1991. Untersuchungen zur terrestrischen Biologie von Populationen des Moorfrosches (Rana arvalis Nilsson 1842) unter besonderer Berücksichtigung der Jahresmobilität. PhD Thesis, University of Hamburg.

HEINE, G. 1987. Einfache Mess- und Rechenmethode zur Ermittlung der Überlebenschance wandernder Amphibien beim Überqueren von Strassen. In: Hoelzinger, J. G. and Schmid, G., (eds) Die Amphibien und Reptilien BadenWürttembergs, pp. 473-480. Naturschutz und Landschaftspflege Baden-Württembergs 41. Institut für Ökologie und Naturschutz, Karlsruhe.

HELS, T. 1999. Effects of Roads on Amphibian Populations. PhD Thesis. University of Copenhagen. Ministry of Environment and Energy, National Environmental Research Institute.

HISTORISCHE ATLAS DRENTHE. 1989. Robas Producties, Den Ilp, The Netherlands.

HITCHINGS, S. P. AND BEEBEE, T. J.C. 1997. Genetic substructuring as a result of barriers to gene flow in urban Rana temporaria (common frog) populations. Heredity, 79, 117-127.

LEVINS, R. 1970. Extinction. In: Gerstenhaber, M. (ed.) Some Mathematical Questions in Biology, pp. 77-107. Lectures on Mathematics in Life Sciences, 2. American Mathematical Society, Providence RI.

LOMAN, J. 1987. Ecological studies on a moor frog population in southern Sweden. In: Glandt, D. and Podloucky, R. (eds) Der Moorfrosch - Metelener Artenschutzsymposium, pp. 139-140. Beiheft Schriftenreihe für Naturschutz und
Landschaftspflege Niedersachsens 19. Niedersaechsisches Landesverwaltungs AMT, Hannover.

MANLY, B. F. J. 1997. Randomization, Bootstrap and Monte Carlo Methods in Biology, 2nd edn. Chapman \& Hall, London

MANTEL, N. 1967. The detection of disease clustering and a generalized regression approach. Cancer Res., 27, 209-220.

MCCAULEY, D. E. 1991. Genetic consequences of local population extinction and recolonization. Trends Ecol. Evol., 6, 5-8.

NEI, M. 1972. Genetic distance between populations. Am. Nat., 106, 283-292.

OPDAM, P. 1990. Dispersal in fragmented populations: the key to survival. In: Bunce, R. G. H. and Howard, D. C. (eds) Species Dispersal in Agricultural Habitats, pp. 3-17. Belhaven Press, London.

OPDAM, P., VANAPELDOORN, R., SCHOTMAN, A. AND KALKHOVEN, J. 1993. Population responses to landscape fragmentation. In: Vos, C. C. and Opdam, P. (eds) Landscape Ecology of a Stressed Environment, pp. 147-171. Chapman \& Hall, London.

PEARSON, W. R. AND LIPMAN, D. J. 1988. Improved tools for biological sequence comparison. Proc. Natl. Acad. Sci. U.S.A., 85, 2444-2448.

PECHMANN, J. H. K. AND SCOTT, D. E. 1991. Declining amphibian populations - The problem of separating human impacts from natural fluctuations. Science, 253, 892-895.

PODLOUCKY, R. 1987. Zur Verbreitung und Bestandssituation des Moorfrosches (Rana arvalis Nilsson) in Niedersachsen. In: Glandt, D. and Podloucky, R. (eds) Der Moorfrosch Metelener Artenschutzsymposium, pp. 15-27. Beiheft Schriftenreihe für Naturschutz und Landschaftspflege Niedersachsens 19. Niedersaechsisches Landesverwaltungs AMT, Hannover.

PROVINCIE DRENTHE. 1994. Verkeerswaarnemingen Drenthe 1993. Provincie Drenthe, Assen.

RAFÍNSKI, J. AND BABIK, w. 2000. Genetic differentiation among northern and southern populations of the moor frog Rana arvalis in central Europe. Heredity, 84, 610-618.

RAHMEL, U. AND EIKHORST, R. 1988. Untersuchungen an den Laichplätzen von Moorfrosch (Rana arvalis) und Grasfrosch (Rana temporaria) auf den nordfriesischen Geestinseln Amrum, Föhr und Sylt. Jahrb. Feldherpetologie, 2, 47-66.

RYSER, J. 1988. Amphibien und Verkehr, Teil 2. Amphibienrettungsmassnahmen an Strassen in der Schweiz - gegenwärtiger Stand, Erfahrungen und Bedeutung für den Artenschutz. Koordinationsstelle für Amphibien und Reptilienschutz in der Schweiz, Bern.

SCHNEIDER, S., ROESSLI, D. AND EXCOFFIER, L. 2000. ARLEQUIN, version 2.000: A software for population genetic analysis. Genetics and Biometry Laboratory, University of Geneva, Switzerland.

SCRIBNER, K. T., ARNTZEN, J. W. AND BURKe, T. 1994. Comparative analysis of intra- and interpopulation genetic diversity in Bufo bufo, using allozyme, single-locus microsatellite, minisatellite and multilocus minisatellite data. Mol. Biol. Evol., 11, 737-748. 
SMULDERS, M. J. M., BREDEMEIJER, G., RUS-KORTEKAAS, W., ARENS, P. ET AL. 1997. Use of short microsatellites from database sequences to generate polymorphisms among Lycopersicon esculentum cultivars and accessions of other Lycopersicon species. Theor. Appl. Genet., 97, 264-272.

SMULDERS, M. J. M., RUS-KORTEKAAS, W. AND VOSMAN, B. 2000. Microsatellite markers useful throughout the genus Dianthus. Genome, 43, 208-210.

TURCHIN, P. 1998. Quantitative Analysis of Movement; Measuring and Modelling Population Redistribution in Animals and Plants. Sinauer, Sunderland MA.

VAN GELDER, J. J. 1973. A quantitative approach to the mortality resulting from traffic in a population of Bufo bufo L. Oecologia, 13, 93-95.

vos, C. C. AND CHARDON, J. P. 1998. Effects of habitat fragmentation and road density on the distribution pattern of the moor frog Rana arvalis. J. Appl. Ecol., 35, 44-56.
VOSMAN, B., ARENS, P., RUS-KORTEKAAS, W. AND SMULDERS, M. J. M. 1992. Identification of highly polymorphic DNA regions in tomato. Theor. Appl. Genet., 85, 239-244.

WASER, P. M. AND STROBECK, C. 1998. Genetic signatures of interpopulation dispersal. Trends Ecol. Evol., 12, 43-44.

WIENS, J. A. 1997. Metapopulation dynamics and landscape ecology. In: Hanski, I., and Gilpin, M. E. (eds) Metapopulation Biology; Ecology, Genetics, and Evolution, pp. 43-68. Academic Press, San Diego.

WRIGHT, S. 1965. The interpretation of population structure by $F$-statistics with special regard to systems of mating. Evolution, 19, 395-420.

YEH, F. C., YANG, R.-C. AND BOYLE, T. 1999. POPGENE, version 1.31. Microsoft Window-based freeware for population genetic analysis. Quick User Guide. University of Alberta, Alberta, Canada. 